\title{
CRYPTOCURRENCIES LEGAL REGULATION
}

\author{
IRINA CVETKOVA, \\ Baltic International Academy (Riga, Latvia)
}

DOI: 10.21684/2412-2343-2018-5-2-128-153

This article evaluates the legal framework of cryptocurrency in various countries. The new currency instrument is abstract currencies. They are currencies in the sense that they can be exchanged peer-to-peer. They are representations of numbers, i.e. abstract objects. An abstract currency system is a self-enforcing system of property rights over an abstract instrument which gives its owners the freedom to use and the right to exclude others from using the instrument. Cryptocurrency or virtual currency is a cryptographically protected, decentralized digital currency used as a means of exchange. Due to the development of new technologies and innovations, the rate of use of virtual currency is rapidly increasing throughout the globe, replacing not only cash payments and payments by bank transfer, but also electronic cash payments. Among the best-known representatives of cryptocurrencies are Bitcoin, Litecoin and Ethereum. Legal scholars have not yet reached a consensus regarding the nature and legal status of virtual currency. Virtual currency possesses the nature of obligations rights as well as property rights, since it may be both a means of payment and a commodity. Depending on the country, the approach to cryptocurrencies may be different. Today there is already an international cryptocurrency community that does not have a single coordinating center. Only progressive jurisdiction and state regulation of cryptocurrency activity will allow the creation of the conditions that will ensure the implementation of legitimate and safe cryptocurrency relations.

Keywords: bitcoin; blockchain; cryptocurrency; e-money; mining; token; virtual currency.

Recommended citation: Irina Cvetkova, Cryptocurrencies Legal Regulation, 5(2) BRICS Law Journal 128-153 (2018). 


\section{Introduction}

Cryptographic currencies appeared due to technological progress and the evolution of money as a completely liquid medium of exchange. Indeed, originally money fulfilled the function of the exchange of goods. It was then assigned to gold as the universal equivalent. The next stage was the transition to paper money, until, today, we have the emergence of electronic money (e-money).

Money is first and foremost a social convention, which emerges to build trust between strangers in their economic transactions, both inter-temporal and in spot markets. A convention of monetary exchange facilitates valuable inter-temporal exchanges that would not occur otherwise.

According to this view, individuals who may neither know nor trust each other choose to settle their transactions by offering symbolic objects-bank deposits or banknotes, for instance, in exchange for labor, goods and services because they find this trading arrangement superior to the available alternatives. ${ }^{1}$

A monetary system can thus be viewed as a social convention that emerges to build the trust needed to support valuable economic interactions between strangers. In a way, confidence in the institution of money can shore up the lack of trust in other members of society. Laboratory research provides some empirical support for this view. ${ }^{2}$

Historically, public confidence in a currency largely referred to the quality of the coins that formed the basis of the currency. States had an obvious advantage over private issuers in guaranteeing this quality, not only because they could set and enforce quality standards more easily than private issuers, but also because states can internalize the long-run benefits of a stable currency, thus strengthening the incentive to avoid debasements. ${ }^{3}$

Digital money or e-money has been around for a long time. The main forms of e-money are commercial bank reserves with the central bank and the money created by commercial banks when they make loans.

The past ten years have seen the creation of a new class of digital instruments that are not issued by a sovereign institution or commercial bank, are not denominated in a sovereign unit and do not have physical counterparts. Since these instruments may be used as a currency, they are variously labeled "electronic cash," "digital currency," "virtual currency," or "cryptocurrency."

Gabriele Camera et al., Money and Trust Among Strangers, 110(37) Proceedings of the National Academy of Sciences 14889 (2013).

2 Gabriele Camera \& Marco Casari, The Coordination Value of Monetary Exchange: Experimental Evidence, 6(1) American Economic Journal: Microeconomics 290 (2014).

3 Charles A.E. Goodhart, The Two Concepts of Money: Implications for the Analysis of Optimal Currency Areas, 14(3) European Journal of Political Economy 407 (1998). 


\section{Definition and Type of Virtual Currency}

The new currency instrument is abstract currencies. They are currencies in the sense that they can be exchanged peer-to-peer. They are representations of numbers, i.e. abstract objects. An abstract currency system is a self-enforcing system of property rights over an abstract instrument which gives its owners the freedom to use and the right to exclude others from using the instrument.

Virtual currency is unlike money in that it is theoretically defined as cryptographically decentralized digital currency, whose issuer is decentralized, and is used as a means of exchange. It is not currency in a literal sense; it does not fulfill the basic characteristics of currency; for example, it is not acknowledged by the State. ${ }^{4}$

However, some experts argue that virtual currency is essentially not much different from standard currency. In its essence, only a small part of our economy is made up of cash; most of the money is in electronic form, which means only the data stored on a computer. The State no longer backs its currency with gold. The current system of legal currency works on mutual trust between the people and the monetary institutions and government, all of whom believe that the legal currency will still have value in the future. Virtual currency is also based on trust among its users that in the future it will still have value. ${ }^{5}$

The European Commission currently provides a working definition of virtual currency as follows:

[lt is] a digital representation of value that is neither issued by a central bank or a public authority, nor necessarily attached to a fiat currency, but is accepted by natural or legal persons as a means of payment and can be transferred, stored or traded electronically. ${ }^{6}$

Data on transactions stored on the software platform blockchain, or distributed ledger technology, underpins many virtual currencies, but can also be used within private, permissioned ledger systems - versions of public and private systems may be used by financial institutions, governments and cross-industry.

4 David L.K. Chuen, Handbook of Digital Currency: Bitcoin, Innovation, Financial Instruments, and Big Data 310 (London: Elsevier, 2015).

5 Benjamin Guttmann, The Bitcoin Bible: All You Need to Know About Bitcoins 123-124 (Germany: BoD, 2013).

6 European Commission, Proposal for a directive of the European Parliament and of the Council amending Directive (EU) 2015/849 on the prevention of the use of the financial system for the purposes of money laundering or terrorist financing and amending Directive 2009/101/EC (Jun. 18, 2018), available at https://eur-lex.europa.eu/legal-content/EN/TXT/?uri=CELEX\%3A52016PC0450.

Marco lansiti \& Karim R. Lakhani, The Truth About Blockchain, Harvard Business Review, January February 2017 (Jun. 18, 2018), available at https://hbr.org/2017/01/the-truth-about-blockchain. 
Abstract currency payments are not intermediated - although they take place over the internet, they are peer-to-peer like cash - they are settled as soon as enough system participants agree they are valid.

The general arguments for a successful distributed cryptocurrency are as follows:

1. Open-source software: A core and trusted group of developers is essential to verify the code and possible changes for adoption by the network.

2. Decentralized: Even if it is not fully distributed, it is essential that it is not controlled by a single group of persons or entity.

3. Peer-to-peer: While the idea is not to have intermediaries, there is a possibility of pools of subnetworks forming.

4. Global: The currency is global, and this is a very positive point and workable for financial integration with or without smart contracts among the parties.

5. Fast: The speed of transaction can be faster and confirmation time can be shortened.

6. Reliability: The advantage is that there is no settlement risk and it is nonrepudiable. The savings in cost of a large settlement team for financial activities can be potentially huge.

7. Secure: Privacy architecture can be better designed incorporating proof of identity with encryption. If that is done, the issues surrounding Know Your Customer/ Client (KYC) and anti-money laundering and terrorist financing (AML/TF) will be resolved.

8. Sophisticated and flexible: The system will be able to cater to and support all types of assets, financial instruments and markets.

9. Automated: Algorithm execution for payments and contracts can be easily incorporated.

10. Scalable: The system can be used by millions of users.

11. Platform for integration: It can be designed to integrate digital finance and digital law with an ecosystem to support smart contracts with financial transactions. Customized agreements can be between multiple parties, containing user-defined scripted clauses, hooks and variables. ${ }^{8}$

According to CoinMarketCap - Forbes, there are more than 1,100 kinds of virtual currencies in the world, and this data is changing all the time. Among the best-known representatives of cryptocurrencies are Bitcoin, Litecoin, Ethereum, Dash and XYO. The most popular virtual currency is Bitcoin (BTC); it is a cryptographically protected peer-to-peer payment system. It takes up $40 \%$ of the cryptocurrency market. Bitcoin is called "digital gold."The value of Bitcoin is based on trust that it will have value also in the future. However, the value varies greatly. In December 2014 one bitcoin had a value of US\$310, whereas in December 2017 its value was US\$20,000.9

8 Chuen 2015, at 12-13.

9 Global Bitcoin Price Index, BitcoinAverage (Jun. 18, 2018), available at https://bitcoinaverage.com/ en/bitcoin-price/btc-to-usd. 
It is entirely appropriate to ask why the popularity of virtual currency has risen. One of the reasons is that people's trust in traditional legal currencies has weakened. For example, the virtual currency Bitcoin was born in response to the outbreak of the global financial crisis in 2008 as a reaction to the failure of the financial system. Some media report about the correspondence of the declining confidence in legal currencies (e.g. the euro and the U.S. dollar) and the increase in the purchase of bitcoins.

Bitcoin is not an investment instrument, an equity or a bond, but primarily a currency and a means of exchange. In April 2017, Japan formally legalized Bitcoin and recognized it as legal tender. In some cities of Switzerland, you can even pay taxes with bitcoins, and Swiss Falcon Private Bank has become the first traditional bank that offers to open accounts in BTC.

There is an opinion that Bitcoin is a more reliable means of payment than money and gold because fiat money can be issued by the state in any amount, whereas the maximum amount of bitcoin is only 21 million, more than 16 million of which have already been mined.

Another popular type of virtual currency is Ethereum (ETH), an open-source, public, blockchain-based distributed computing platform and operating system featuring smart contract (scripting) functionality. It accounts for $18 \%$ of the cryptocurrency market, and it is compared to oil.

Cryptocurrency XYO is not an ordinary blockchain-powered start-up. XYO first appeared in the industry in 2012. Since then they have managed to spread 1 million beacons all over the globe. Now they are planning to deploy over 1 million more microdevices, satellites and sticker-based trackers. In the case of XYO Network, the company is looking to combine blockchain technology with crypto-location technologies to provide location-reliant markets with an option to employ transactions which depend on the time or location of delivery. The main purpose of this new project is to create a successful location-based business to get Bluetooth and GPS tracking beacons out into the world. The current use cases span industries including e-commerce, logistics and rental car agencies, among others. With over 1 million devices out in the world already, the project is certainly off to a good start. ${ }^{10}$

The banking sector too has not been immune to the popularity of virtual currency. In August 2017, the world's six largest banks - Barclays, Credit Suisse, the Canadian Imperial Bank of Commerce, HSBC, MUFG and State Street - launched a project to create their own cryptocurrency. ${ }^{11}$

The emission and mining of virtual currency, its use for settlements as well as turnover are not fully regulated and are not under the supervision at the state or

10 JP Buntinx, What Is XYO Cryptocurrency?, Null TX, 21 March 2018 (Jun. 18, 2018), available at https:// nulltx.com/what-is-xyo-cryptocurrency/.

11 Martin Arnold, Six Global Banks Join Forces to Create Digital Currency, Financial Times, 31 August 2017 (Jun. 18, 2018), available at https://www.ft.com/content/20c10d58-8d9c-11e7-a352-e46f43c5825d. 
national level, and the legal regulation associated with it is currently under construction. Cryptocurrency is not tied to any of the national currencies, and at the same time it is a commodity.

The measure of the value of the cryptocurrency depends on the following main factors:

1) value offer, as well as other actions of the issuer; for example, maintaining a fixed or semi-fixed exchange rate;

2) network dimensions. The cost of the currency depends on how many users, and with what level of income, are accepted into the network. With the growth in the size of the network (i.e. consumers and sellers), the value of the currency increases proportionally;

3) the institutional conditions governing the virtual community, that is, virtual communities that have a transparent policy and modern security measures are highly trusted, which is a prerequisite for creating a more valuable cryptocurrency;

4) reputation of the issuer of the cryptocurrency to fulfill its obligations. In carrying out payments by cryptocurrency, for the lender there is no authority responsible for the reliability of the transaction, therefore one of the most important elements influencing the virtual rate is the trust accumulated by the issuer of the cryptocurrency;

5) assumptions about the future value of the currency and the history of cyberattacks of victims in the virtual community.

\section{Legal Status of Cryptocurrencies}

\subsection{Cryptocurrency is Money}

Supporters of this position note the similarity of some functions of cryptocurrency with monetary means. Cryptocurrency can be a means of payment for goods and services, and, for example, U.S. law specifically stipulates that it can be a payment unit in which wages are paid.

In some countries, cryptocurrency has become a unit of settlement which is recognized and accepted by various subjects in the market.

The U.S. Financial Crimes Enforcement Network (FinCEN) believes that transactions involving the exchange of cryptocurrency for fiat money should be regulated in the same way as the operations involving the exchange of fiat money alone. Legal entities involved in the flow of funds with cryptocurrencies are required to obtain licenses.

Japan has recognized cryptocurrency Bitcoin fiat money as having the same function as money. Accordingly, the government decided to develop a regulatory framework for the full integration of the cryptocurrency into the banking system of Japan. The national regulator for the cryptocurrency is the Financial Services Agency of Japan, which regulates issues in respect of the emission of national currency. 


\subsection{Cryptocurrency is a Money Surrogate}

The opponents of identifying cryptocurrency as the equal of the ordinary money note argue that cryptocurrency is not a monetary instrument since the state does not issue it, does not guarantee its value and does not establish the obligation that it be accepted. In the vast majority of jurisdictions, cryptocurrency is not recognized as an official means of payment and does not apply to money. For example, the tax service of the Netherlands does not consider cryptocurrency to be a legal means of payment, and the Central Bank of Denmark announced in 2014 that Bitcoin is not a currency. From the point of view of the Danish regulator, this cryptocurrency has no real trade value compared to gold or silver and is more comparable to glass beads. ${ }^{12}$

\subsection{Cryptocurrency is Electronic Money}

In international law, the definition of electronic money was fixed in 1998 by a report on electronic money of the European Central Bank (ECB). Electronic money is broadly defined as the electronic storage of monetary value on a technical device that can be widely used to make payments in favor of not only the issuer, but also other companies, and that does not require the mandatory use of bank accounts for transactions, but acts as a prepaid instrument to a bearer. ${ }^{13}$

The supporters of the position that cryptocurrency is a type of electronic money point out that cryptocurrency has no issuers as electronic means of payment. It can be considered to be cash, which is traditionally provided by one person to another person, without opening a bank account to fulfill monetary obligations.

According to the Electronic Money Directive (2009/110/EC), electronic money is a monetary value which follows from the submitted requirements to the issuers: this value should be stored electronically; the electronic money itself must be issued in order to receive funds. ${ }^{14}$

In the systems of cryptocurrency the unit of account has been changed. This important problem is defined by the ECB as follows:

1) these systems rely on a certain exchange rate which can fluctuate since the value of the cryptocurrency is usually based on its own supply and demand;

2) the connection with the traditional currency is lost to some degree, which could be problematic when restoring funds, even if it is allowed;

12 The Danish Central Bank went on to point out that bitcoins are not protected by any national laws or guarantees, such as a deposit guarantee. Danmarks Nationalbank, Bitcoin er ikke penge (Jun. 18, 2018), available at http://www.nationalbanken.dk/da/presse/Documents/2014/03/PH_bitcoin.pdf\# search=Bitcoin.

13 European Central Bank, Report on Electronic Money (August 1998) (Jun. 18, 2018), available at https:// www.ecb.europa.eu/pub/pdf/other/emoneyen.pdf.

14 Directive 2009/110/EC of the European Parliament and of the Council of 16 September 2009 on the taking up, pursuit and prudential supervision of the business of electronic money institutions amending Directives 2005/60/EC and 2006/48/EC and repealing Directive 2000/46/EC, 2009 O.J. (L 267) 7. 
3) the fact that the currency is called differently (that is, not the euro, the U.S. dollar, etc.) and the fact that monetary funds should not be redeemed at face value (nominal par), means that full control over the cryptocurrency is left to its issuer, which is usually a non-profit organization;

4) electronic money systems are regulated by regulatory enactments, and the founders of the electronic money systems, which conduct emission of the payment means in the form of electronic money, are subject to appropriate administrative requirements and control. For the cryptocurrency systems, the risks faced by each type of currency differ.

Electronic money is primarily exposed to an operational risk associated with the potential malfunction of the system on which it is stored. Cryptocurrencies are not only under the influence of credit, operational and liquidity risks without any legal protection, but these schemes are also subject to the legal risk of security breach and fraud as a result of the lack of regulation and public oversight.

The definition of the cryptocurrency systems used in this ECB report excludes such objects as PayPal - a payment system established on the internet. The PayPal account is financed through a credit transfer of a bank account or by a credit card payment, that is, it operates within the banking system. Furthermore, PayPal falls under the regulation of the Commission de Surveillance du Secteur Financier of Luxembourg, ${ }^{15}$ whereas the electronic money system is supervised by Banque centrale du Luxembourg.

The opponents of this point of view emphasize that the main difference between cryptocurrency and electronic money is the absence of an intermediary in the transactions that verifies the payment, since when paying in cryptocurrency the calculation is carried out one subject to another directly.

\subsection{Cryptocurrency is a Financial Instrument}

A financial instrument is a security or its derivative. Moreover, the derivative is a contract that, as one of the options, provides for the realization of the obligation to buy or sell securities, currency or goods.

The underlying asset of a derivative financial instrument can be a currency, commodity or securities as well as various statistical indicators, indices and percentages. Accordingly, if cryptocurrency is not a commodity or a security, it will not be the underlying asset for the derivative financial instrument.

The position that cryptocurrency can be a financial instrument was taken by the German Ministry of Finance. In 2013, it issued a decree on recognizing cryptocurrency as an official means of settlement. At the same time, the law clearly delineates this status from the status of a legal means of payment-cryptocurrency has not received such a status in Germany yet.

15 Commission de Surveillance du Secteur Financier (CSSF) [Financial Sector Surveillance Commission] (Jun. 18, 2018), available at http://www.cssf.lu/en/. 


\subsection{Cryptocurrency is a Commodity}

A commodity is a material or non-material object that can be used in economic terms. In a number of countries, cryptocurrency is treated as property or a commodity and is taxed. The legal systems of these countries qualify cryptocurrency as an inexhaustible non-material commodity with a definite value at each particular moment.

The Australian Tax Service does not consider cryptocurrency as money or foreign currency, equating operations with its participation to barter agreements (barter arrangement). ${ }^{16}$

In September 2015, the Commodity Futures Trading Commission (CFTC) recognized the Bitcoin cryptocurrency as a commodity. ${ }^{17}$ In 2017, the Israel Tax Service published a draft circular in which the cryptocurrency is qualified as a digital unit having a nominal value that can be used for barter or for investment purposes. ${ }^{18}$

\subsection{Cryptocurrency is a Security}

The U.S. Securities and Exchange Commission (SEC), in their report on the investigation of the situation regarding a blockchain startup "The DAO," pointed out that the issuance of ICO (initial coin offering) tokens (a token is a unit of value issued by a private organization in the blockchain system) must be considered to be securities regardless of what the thing the investors had invested their money in was called and how it worked. ${ }^{19}$

The opponents of such a position argue that cryptocurrency does not contain liability rights and is not a monetary obligation. They rely on the fact that the relations that are contained in the transaction of cryptocurrencies are most comparable in nature to the barter agreement.

The emission of cryptocurrency is carried out on the internet in a decentralized manner and therefore does not meet the concept of the emission of securities. The issuer is each participant of the payment system, since the transaction creates a new block in the transaction chain. On this basis, cryptocurrency does not meet the characteristics of securities and is not a security itself.

16 Australian Government, Australian Taxation Office, Tax Treatment of Cryptocurrencies (Jun. 18, 2018), available at https://www.ato.gov.au/General/Gen/Tax-treatment-of-crypto-currencies-in-Australia--specifically-bitcoin/.

17 Commodity Futures Trading Commission, Order Instituting Proceedings Pursuant to Sections 6(c) and 6(d) of the Commodity Exchange Act, Making Findings and Imposing Remedial Sanctions, 17 September 2015 (Jun. 18, 2018), available at https://www.cftc.gov/sites/default/files/idc/groups/public/@ Irenforcementactions/documents/legalpleading/enfcoinfliprorder09172015.pdf.

18 Jenny David, Israel Seeks Tax on Bitcoin, Bloomberg BNA, 24 January 2017 (Jun. 18, 2018), available at https://www.bna.com/israel-seeks-tax-n73014450141/.

19 SEC Issues Investigative Report Concluding DAO Tokens, a Digital Asset, Were Securities: U.S. Securities Laws May Apply to Offers, Sales, and Trading of Interests in Virtual Organizations, Press Release, 25 July 2017 (Jun. 18, 2018), available at https://www.sec.gov/news/press-release/2017-131. 


\subsection{Cryptocurrency is Property}

The Internal Revenue Service (IRS) of the United States has issued guidance on the taxation of transactions with Bitcoin and other cryptocurrencies, according to which they can be qualified as:

1) currency,

2) property, and

3) investment instruments (long-term investment in shares). ${ }^{20}$

For the purposes of payment of U.S. federal taxes, Bitcoin is considered to be property, upon sale of which the owners will not receive the profit from the exchange rate differences, but the profit from the capital gains.

At the same time, payment of wages in cryptocurrencies is subject to income tax and salary tax, and payments in cryptocurrencies to independent contractors are taxed applying the self-employment tax.

\section{Legal Regulation of Virtual Currencies in Non-European Countries}

In a number of non-European countries the approach to cryptocurrencies is different.

Argentina. Virtual currencies are not legal tender under the country's National Constitution, which designates the Central Bank as the only authority that may issue legal tender. ${ }^{21}$

In Australia, virtual currency is not considered to be a financial product, and, consequently, cryptocurrency activity is not subject to license (except for activities associated with fiat money or other financial instruments). The Australian Digital Currency Industry Code of Conduct developed by the Australian Digital Currency \& Commerce Association establishes the proper standards for conducting cryptocurrency business in the country, but is mandatory for execution only for the members of the Association. ${ }^{22}$

Brazil. Brazil's Securities Exchange Commission, Comissão de Valores Mobiliários (CVM), has determined that the digital currency Niobium Coin (NBC) is not a financial asset. The CVM has stated that virtual currencies are to be considered securities only when they pay interest or dividends to their investors, or when they allow for participation in company management through votes. ${ }^{23}$

20 New IRS Notice Confirms Tax Treatment of Bitcoins as Property and Not Currency - Expected to Increase Popularity for Self-Directed IRAs, According to IRA Financial Group, Cision PRWeb, 25 March 2014 (Jun. 18, 2018), available at http://www.prweb.com/releases/bitcoins-self-directed-/ira-taxproperty-currency/prweb11704323.htm.

Ignacio Olivera Doll \& Camila Russo, Argentina's Biggest Futures Market Plans to Join the Bitcoin Party, Bloomberg, 2 November 2017 (Jun. 18, 2018), available at https://www.bloomberg.com/news/ articles/2017-11-02/argentina-s-biggest-futures-market-plans-to-join-bitcoin-party.

22 Tax Treatment of Cryptocurrencies, supra note 16.

23 Brazilian SEC Confirms: Digital Currency Niobium Coin (NBC) Is Not a Financial Asset, Markets Insider, 22 January 2018 (Jun. 18, 2018), available at http://markets.businessinsider.com/news/stocks/braziliansec-confirms-digital-currency-niobium-coin-nbc-is-not-a-financial-asset-1013591426. 
Canada ranks as second in the world after the United States in terms of the number of installed bitcoin ATMs. Payment for goods or services with the help of the cryptocurrency in Canada is subject to taxation as a barter transaction. In case of sale of the digital currency, income tax, a corporation income tax or a capital gains tax is levied. ${ }^{24}$

In China, a general approach to the legal regulation of cryptocurrency transactions has not been worked out yet. The current Chinese legislation does not contain any special rules for taxation of virtual currency and transactions with it. At the same time, in the announcement of the National Bank of 2013, cryptocurrency is defined as a virtual commodity, not a currency, and may be taxed with the value-added tax, and income and profit in the cryptocurrency are subject to a corporate tax, individual income tax and capital gains tax. ${ }^{25}$

Cyprus. The Central Bank directly acknowledged for the first time recently that Bitcoin is not illegal, but highlighted the risks of using an unregulated digital currency. The banking regulator has twice previously issued a warning to consumers saying there are risks involved in trading in virtual currencies, in line with a December 2017 ruling issued by the European Banking Authority (EBA). This action resulted in the hesitation by the Cyprus Stock Exchange and the Securities and Exchange Commission (CySEC), despite its initial eagerness, to allow bitcoin-traded products, such as derivatives. ${ }^{26}$

Ecuador has banned the issuance, promotion or circulation of virtual currencies and plans to issue its own digital currency for use as legal tender. Ecuador's official fiat currency is the U.S. dollar, and the digital currency under Ecuador's Electronic Currency System will be "equivalent and convertible to U.S. dollars."

Hong Kong. Regarding the status of cryptocurrency, the authorities recognize that this sphere is not regulated by law and warn that criminal responsibility exists for fraudulent operations. This position has been taken by Hong Kong since 2014. At the moment, the government does not consider it necessary to introduce (adopt) new legislation on the regulation of trade (of cryptocurrencies) in such virtual goods or to prohibit citizens from participating in such transactions (with cryptocurrency). ${ }^{28}$

24 Government of Canada, What You Should Know About Digital Currency (Jun. 18, 2018), available at https://www.canada.ca/en/revenue-agency/news/newsroom/fact-sheets/fact-sheets-2013/whatyou-should-know-about-digital-currency.html.

25 Vitalik Buterin, China Releases First Regulatory Report on Bitcoin Businesses, Bitcoin Magazine, 5 December 2013 (Jun. 18, 2018), available at https://bitcoinmagazine.com/articles/china-releases-firstregulatory-report-on-bitcoin-businesses-1386283989/.

26 Elias Hazou, Central Bank Says Bitcoin Is Not Illegal, CyprusMail, 26 February 2014 (Jun. 18, 2018), available at http://cyprus-mail.com/2014/02/26/central-bank-says-bitcoin-is-not-illegal/.

27 Belén Marty, Ecuadorian Banks Must Adopt Official Electronic Currency or Else, PanAm Post, 31 May 2015 (Jun. 18, 2018), available at https://panampost.com/belen-marty/2015/05/31/ecuadorian-banksmust-adopt-official-electronic-currency-or-else/.

28 Leonhard Weese, Hong Kong Report Suggests Cryptocurrency Is Largely Left Out of City's Organized Crime, Forbes, 30 April 2018 (Jun. 18, 2018), available at https://www.forbes.com/sites/leonhard 
India. In 2013, the authorities stated that they did not want to regulate the turnover of Bitcoin. In 2016-2017, a massive tightening of rules on the circulation of funds began; the authorities actually arbitrarily began to take gold away from citizens; simultaneously, blockchain-solutions for the banks and other innovations became more available.

The fundamental stand of the Reserve Bank of India (RBI) with regard to Bitcoin and other cryptocurrencies is that they are not legal tender currencies. They cannot be used for payments as usual currencies. Rather, they have big risks without any regulation and support. The RBI has issued warnings three times, first in December 2013, then in February 2017 and finally on 5 December 2017. The initial caution by the RBI in 2013 explains why investment in virtual currencies such as Bitcoin is risky. ${ }^{29}$

Indonesia. Bank Indonesia has warned that cryptocurrencies may not be used for payments in the country and payment firms are not allowed to make virtual currency transactions. Bank Indonesia affirms that it forbids all payment system operators (principal, switching operator, clearing operator, final settlement operator, issuer, acquirer, payment gateway operator, electronic wallet operator, money transfer operator) and financial technology operators in Indonesia, both bank and non-bank institutions, from processing transactions using virtual currency, as stated in Bank Indonesia Regulation No. 18/40/PBI/2016 on Implementation of Payment Transaction Processing and Bank Indonesia Regulation No. 19/12/PBI/2017 on Implementation of Financial Technology. ${ }^{30}$

Israel. The Israeli central bank and Finance Ministry have issued warnings to the public about the risks associated with virtual currencies. Israel's central bank has said it would view virtual currencies such as Bitcoin as financial assets, not as a currency. The Israel Securities Authority (ISA) has recommended lenient ICO regulations which would include clear guidance on what constitutes a security that triggers securities law, as opposed to a utility token, which the ISA indicated should not necessarily be deemed a security by virtue of its conferring "usage rights in a product or service."131

Japan is a world leader in innovation and the cryptocurrency industry. Its Japan Authority of Digital Assets is a self-regulatory authority. In 2016, a law was put in place that regulates the activities of exchanges: they are now subject to registration with the

weese/2018/04/30/hong-kong-report-suggests-cryptocurrency-is-largely-left-out-of-citys-organizedcrime/\#78b6bf303775.

29 Tojo Jose, Cryptocurrency Regulation in India, Indian Economy, 7 January 2018 (Jun. 18, 2018), available at https://www.indianeconomy.net/splclassroom/cryptocurrency-regulation-in-india/.

30 Sujha Sundararajan, Indonesia Central Bank: Cryptocurrency Payments "Not Legitimate," CoinDesk, 15 January 2018 (Jun. 18, 2018), available at https://www.coindesk.com/indonesias-central-bankcryptocurrency-payments-not-legitimate/.

31 Israel: The Hotspot for Blockchain Innovation, Deloitte (February 2016) (Jun. 18, 2018), available at https://www2.deloitte.com/content/dam/Deloitte/il/Documents/financial-services/israel_a_ hotspot_for_blockchain_innovation_feb2016_1.1.pdf. 
Financial Services Agency, which can conduct inspections of such businesses and apply appropriate administrative measures. In accordance with this law, cryptocurrency is an asset-like value. Virtual currency and transactions with it are subject to taxation in accordance with the standard rules: the income received by an individual in the form of a cryptocurrency is subject to income tax; the profit gained by a legal entity in digital currency is subject to corporate income tax; the sale of cryptocurrency is subject to the Japanese analogue of the Consumption Tax. ${ }^{32}$

In Jordan, virtual currencies are not legal tender and the central bank has warned against their use. Banks, currency exchanges, financial companies and payment service providers operating in Jordan are prohibited from dealing in virtual currencies. ${ }^{33}$

Lebanon. In 2017, the governor of the Banque du Liban (BDL), Lebanon's central bank, reported that his institution has banned the use of cryptocurrencies. Bitcoin and other cryptocurrencies remain a significant threat to consumers and payment systems. He announced that the BDL would, in the next few years, release its own digital currency in compliance with Lebanese law, although he did not specify whether this store of value would be a true cryptocurrency. ${ }^{34}$

Malaysia. Virtual currencies were previously not legal tender in Malaysia, but the government will enforce new cryptocurrency regulation soon. ${ }^{35}$

In Mexico, cryptocurrencies are not legal tender currency. The lower house of Mexico's Congress approved legislation for FinTech companies and gave legal clarity for ICOs, payment methods and cryptocurrencies generally. Additionally, the law would permit open banking (sharing of user information by financial institutions) through public application programming interfaces (APIs). Details of the regulation will be determined by the CNBV (banking and securities regulator), the central bank and the Finance Ministry. Mexico's Senate approved a version of the bill in December 2017, which now awaits President Nieto's signature. ${ }^{36}$

Nigeria. Nigeria does not regulate or recognize cryptocurrency as legal currency. The Central Bank of Nigeria (CBN) has not approved the use of cryptocurrency for

32 Diet OKs Bill to Regulate Virtual Currency Exchanges, The Japan Times, 25 May 2016 (Jun. 18, 2018), available at https://www.japantimes.co.jp/article-expired/\#.WFGw4vmLTIV.

33 Omar Obeidat, Central Bank Warns Against Using Bitcoin, The Jordan Times, 22 February 2014 (Jun. 18, 2018), available at http://www.jordantimes.com/news/local/central-bank-warns-against-usingbitcoin.

34 Adam Reese, Lebanon's Central Bank Bans Cryptocurrency, ETHNews, 31 October 2017 (Jun. 18, 2018), available at https://www.ethnews.com/lebanons-central-bank-bans-cryptocurrency.

35 Deputy Governor's Opening Address at the Asian Banker Digital Finance Convention 2018, Kuala Lumpur, 22 March 2018 (Jun. 18, 2018), available at http://www.bnm.gov.my/index.php?ch= en_speech\&pg=en_speech\&ac $=792$.

36 Reuters Staff, Mexico Financial Technology Law Passes Final Hurdle in Congress, Reuters, 2 March 2018 (Jun. 18, 2018), available at https://www.reuters.com/article/us-mexico-fintech/mexico-financialtechnology-law-passes-final-hurdle-in-congress-idUSKCN1GD6KX. 
any transactions in the country. Various government agencies have issued warnings about cryptocurrencies and ICOs. ${ }^{37}$

Russian Federation. In April 2017, the Central Bank of the Russian Federation recognized virtual currency as a digital commodity, and in February 2018 the Russian Duma began discussion of cryptocurrency legislation - a draft Federal law on digital assets. $^{38}$

The bill provides that mining is an entrepreneurial activity aimed at creating a cryptocurrency and/or validation in order to receive remuneration in the form of cryptocurrency. Cryptocurrency is defined as a type of digital financial asset created and accounted for in the distributed registry of digital transactions by the participants of this registry in accordance with the rules of maintenance of the register of digital transactions. The rules of turnover of cryptocurrencies are not determined by the bill and will be established separately.

Singapore. The Monetary Authority of Singapore (MAS) published a consultation paper proposing legislation for payment services. The proposed bill would expand the scope of regulation to include the purchase and sale of virtual currencies and other innovations used in domestic money transfers and merchant transactions via point-of-sale or online payment gateways. The new legislation would be incorporated into Singapore's existing laws on payment services, the 2006 Money-Changing and Remittance Businesses Act. The draft is the second of its kind and was amended following feedback received from the first consultation paper. ${ }^{39}$

Thailand does not regulate cryptocurrency transactions, but the position of the SEC in Thailand is that Bitcoin is an asset that can be traded. The SEC does not endorse the status of Bitcoin, and Bitcoin is not recognized as legal tender to pay off debt. The Cabinet of Thailand (the executive branch of the Thai government) has approved the drafts of two royal decrees that would regulate digital asset transactions and levy taxes on digital assets. ${ }^{40}$

United States of America. In the United States, prejudicial supervision of virtual currency is the responsibility of the state. For example, the states of Idaho, Louisiana, New York and Washington adopted the concept that the transfer of virtual currency

37 Central Bank of Nigeria, Virtual Currencies Not Legal Tender in Nigeria, Press Release (Jun. 18, 2018), available at https://www.cbn.gov.ng/Out/2018/CCD/Press\%20Release\%20on\%20Virtual\%20 Currencies.pdf.

38 Проект федерального закона "О цифровых активах" [Federal Law Draft “On Digital Assets"] (Jun. 18, 2018), available at https://www.minfin.ru/ru/document/?id_4=121810.

39 Monetary Authority of Singapore, Proposed Payment Services Bill, Consultation Paper P021 - 2017 (November 2017) (Jun. 18, 2018), available at http://www.mas.gov.sg/ /media/resource/publications/ consult_papers/2017/Consultation\%20on\%20Proposed\%20Payment\%20Services\%20Bill\%20 MAS\%20P0212017.pdf.

40 CryptoFinTech in Thailand: The Thai Initial Coin Offering (TICO), Linkedln (Jun. 18, 2018), available at https://www.linkedin.com/pulse/cryptofintech-thailand-thai-initial-coin-offering-tico-eder/. 
and mining are the objects of money transmission in accordance with the law"on the unification of monetary services." In turn, for the implementation of cryptocurrency services, a license is required. ${ }^{41}$

At the federal level, there is the Guidance of the Internal Revenue Service No. 201421 of 25 March 2014, currently in force, according to which virtual currency is a digital reflection of value which acts as a means of exchange, a unit of settlement and a valuable stock. For taxation, digital money in the U.S. is classified as property. ${ }^{42}$

It is as property then that it is considered for taxation purposes; and operations with cryptocurrency are also taxed. For example, the salaries paid to employees with Bitcoin are subject to federal income tax withholding, as well as payroll taxes.

In 2011, FinCEN issued regulations clarifying that a foreign-located business qualifies as a Money Services Business (MSB) if it does business as an MSB "wholly or in substantial part within the United States." According to FinCEN:

Whether or not a foreign-located person's MSB activities occur within the United States depends on all of the facts and circumstances of each case, including whether persons in the United States are obtaining MSB services from the foreign-located person, such as sending money to or receiving money from third parties through the foreign-located person. ${ }^{43}$

In 2013, FinCEN issued guidance providing that any virtual currency "exchanger" (i.e. a person engaged as a business in the exchange of virtual currency for real currency, funds or other virtual currency) is a money transmitter (i.e. a person engaged in the business of accepting and transmitting currency, funds or other value that substitutes for currency) under the Bank Secrecy Act (BSA) and its implementing regulations and, therefore, required to register with FinCEN as an MSB within 180 days of beginning operations. ${ }^{44}$

On 26 July 2017, FinCEN of the U.S. Department of the Treasury announced the assessment of a $\$ 110$ million civil money penalty against Canton Business Corporation (BTC-e), one of the largest virtual currency internet-based exchanges by volume in the world, for its willful violations of federal anti-money laundering

${ }^{41}$ Washington State Department of Financial Institutions, Virtual Currency Regulation (Jun. 18, 2018), available at http://www.dfi.wa.gov/documents/money-transmitters/virtual-currency-regulation. pdf.

42 Financial Crimes Enforcement Network, Application of FinCEN's Regulations to Persons Administering, Exchanging, or Using Virtual Currencies: Guidance (FIN-2013-G001), 18 March 2013 (Jun. 18, 2018), available at https://www.fincen.gov/sites/default/files/shared/FIN-2013-G001.pdf.

43 Id.

44 Financial Crimes Enforcement Network, Bank Secrecy Act Regulations - Definitions and Other Regulations Relating to Money Services Businesses, 76 F.R. 43585, 43588, 21 July 2011 (Jun. 18, 2018), available at www.gpo.gov/fdsys/pkg/FR-2011-07-21/pdf/2011-18309.pdf. 
laws, as well as a $\$ 12$ million civil money penalty against the BTC-e operator and Russian national Alexander Vinnik. ${ }^{45}$

Vietnam. Virtual currencies are not money nor legal tender in Vietnam and the State Bank of Vietnam warns against investing in, holding or transacting in virtual currencies. ${ }^{46}$

\section{Legal Regulation of Virtual Currencies in Europe}

At the same time, a number of countries demonstrate a complete inability to respond adequately and competently to innovations and technological progress. To resolve the legal aspects of virtual currency, the European Union has also faced the need to create the appropriate legal regulation, but does not hurry with its adoption. Currently, there is no single legal definition of virtual currency and general legal regulation in the EU, but some countries of Europe have defined the status of virtual currency for taxation purposes.

The first attempt to provide the basis for a discussion on virtual currency schemes is a European Central Bank report "Virtual Currency Schemes." It is important to take into account that these currencies both resemble money and necessarily come with their own dedicated retail payment systems; these two aspects are covered by the term virtual currency scheme.

Virtual currency schemes are relevant in several areas of the financial system and are therefore of interest to central banks. This, among other things, explains the ECB's interest in carrying out an analysis, especially in view of its role as a catalyst for payment systems and its oversight role.

The ECB report begins by defining and classifying virtual currency schemes based on observed characteristics; these might change in the future, which could affect the current definition. A virtual currency can be defined as a type of unregulated, digital money which is issued and usually controlled by its developers, and used and accepted among the members of a specific virtual community. ${ }^{47}$

Depending on their interaction with traditional, "real" money and the real economy, virtual currency schemes can be classified into three types:

45 Financial Crimes Enforcement Network, FinCEN Fines BTC-e Virtual Currency Exchange \$1 10 Million for Facilitating Ransomware, Dark Net Drug Sales, 26 July 2017 (Jun. 18, 2018), available at https://www. fincen.gov/sites/default/files/2017-07/BTC-e\%20July\%2026\%20Press\%20Release\%20FINAL1.pdf.

46 Ministerio del Poder Popular para Relaciones Interiores, Justicia y Paz, Desmantelado galpón de moneda virtual "Bitcoin" en Carabobo, 27 enero, 2017 [Ministry of the People's Power for Interior, Justice and Peace, Dismantled Shed of Virtual Currency “Bitcoin" in Carabobo, 27 January 2017] (Jun. 18, 2018), available at http://www.mpprijp.gob.ve/index.php/2017/01/27/desmantelado-galpon-demoneda-virtual-bitcoin-en-carabobo/?platform=hootsuite.

47 European Central Bank, Virtual Currency Schemes (October 2012) (Jun. 18, 2018), available at http:// www.ecb.europa.eu/pub/pdf/other/virtualcurrencyschemes201210en.pdf. 
1) those that refer to closed virtual currency schemes, basically used in online games;

2) those that have a unidirectional flow (usually an inflow), i.e. there is a conversion rate for purchasing the virtual currency, which can subsequently be used to buy virtual goods and services, but exceptionally also to buy real goods and services;

3) those that have a bidirectional flow, i.e. the virtual currency in this respect acts like any other convertible currency, with two exchange rates (buy and sell), which can subsequently be used to buy virtual goods and services, but also to purchase real goods and services.

The ECB considers that the absence of a distinct legal framework leads to other important differences as well:

1) traditional financial actors, including central banks, are not involved. The issuer of the currency and scheme owner is usually a non-financial private company. This implies that typical financial sector regulation and supervision arrangements are not applicable;

2) the link between virtual currency and traditional currency (i.e. currency with a legal tender status) is not regulated by law, which might be problematic or costly when redeeming funds, if this is even permitted;

3) the fact that the currency is denominated differently (i.e. not the euro, U.S. dollar, etc.) means that complete control of the virtual currency is given to its issuer, who governs the scheme and manages the supply of money at will.

The ECB considers that in the current situation, virtual currency schemes:

1) do not pose a risk to price stability, provided that money creation continues to stay at a low level,

2) tend to be inherently unstable, but cannot jeopardize financial stability owing to their limited connection with the real economy, their low volume traded and a lack of wide user acceptance,

3) are currently not regulated and not closely supervised or overseen by any public authority, even though participation in these schemes exposes users to credit, liquidity, operational and legal risks,

4) could represent a challenge for public authorities, given the legal uncertainty surrounding these schemes, as they can be used by criminals, fraudsters and money launderers to perform their illegal activities,

5) could have a negative impact on the reputation of central banks, assuming the use of such systems grows considerably and in the event that an incident attracts press coverage, since the public may perceive the incident as being caused, in part, by a central bank not doing its job properly, and

6) do indeed fall within central banks' responsibility as a result of characteristics shared with payment systems, which give rise to the need for at least an examination of developments and the provision of an initial assessment. ${ }^{48}$

48 Virtual Currency Schemes, supra note 47. 
In July 2014, the EBA issued its considered opinion on virtual currencies. From its perspective as a prudential banking policy authority for the European Union, the EBA highlighted a lengthy list of risks to virtual currency participants, existing financial institutions and regulators. The EBA opinion concluded that in the short term only the certain risks that arise during the interaction between virtual currencies and regulated financial institutions are able to be regulated.

These presently regulable risks would include the risk of money laundering and financial crime, contagion risk to conventional payment systems and user-related information risks. For these risks, the EBA has recommended that existing financial institutions should be discouraged from dealing with virtual currencies, thereby "shielding" them while at the same time mandating that virtual currency exchanges comply with anti-money laundering and counter-terrorist financing requirements. ${ }^{49}$

The European Commission has a similar definition that electronic money is a digital equivalent of cash, stored on an electronic device or remotely on a server. On 26 May 2016, the European Parliament adopted a resolution on virtual currencies (2016/2007(INI)) with the aim of implementing an approach for the legal regulation of virtual currency at the EU level and identifying the problems associated with the use of virtual currency. ${ }^{50}$

By the end of 2016, legal regulation at the EU level had been adopted only with regard to preventing the financing of terrorism and the legalization of the proceeds of crime, on the basis of which in October 2016 an Opinion of the European Central Bank was adopted. ${ }^{5}$

Detailed regulation will certainly be a long process, with respect to the fact that the technology itself, which is about to be regulated, is developing faster than the legislator's regulatory attempts.

Belgium. The National Bank of Belgium has warned investors and the public of the dangers of virtual currencies and declared that they are not legal tender; and the Minister of Justice has announced his intention to impose strict regulations on virtual currency activities. ${ }^{52}$

49 European Banking Authority, EBA Opinion on "Virtual Currencies," EBA/Op/2014/08, 4 July 2014 (Jun. 18, 2018), available at http://www.eba.europa.eu/documents/10180/657547/EBA-Op-201408+Opinion+on+Virtual+Currencies.pdf.

50 European Parliament resolution of 26 May 2016 on virtual currencies (2016/2007(INI)) (Jun. 18, 2018), available at $\mathrm{http}: / / \mathrm{www}$.europarl.europa.eu/sides/getDoc.do?type $=$ TA\&language $=E N \&$ reference $=\mathrm{P}$ 8-TA-2016-0228.

51 Opinion of the European Central Bank of 12 October 2016 on a proposal for a directive of the European Parliament and of the Council amending Directive (EU) 2015/849 on the prevention of the use of the financial system for the purposes of money laundering or terrorist financing and amending Directive 2009/101/EC (CON/2016/49) (Jun. 18, 2018), available at https://www.ecb.europa.eu/ecb/legal/pdf/ en_con_2016_49_f_sign.pdf.

52 National Bank of Belgium, Digital Currencies: Threats and Opportunities for Monetary Policy, Press Release, 16 June 2017 (Jun. 18, 2018), available at https://www.nbb.be/en/articles/press-releasedigital-currencies-threats-and-opportunities-monetary-policy. 
The Baltic countries do not hurry with the adoption of legislation on cryptocurrencies either. The most progressive in these terms is Estonia, which is planning to launch a new Estonian digital currency, similar to Bitcoin and Ethereum - Estcoin. ${ }^{53}$ "Blockhive OÜ," owned by Japanese investors, installed equipment for cryptocurrency mining and since the autumn of 2017 has been engaged in the production of cryptocurrency in the industrial park of Estonia Pakri, and it is already expanding its production.

Lithuania and Latvia, when choosing a method for regulating cryptocurrency, are Europe-oriented. In October 2017, the Central Bank of Lithuania outlined the legislative framework that can regulate the cryptocurrency turnover. The laws are applied by proceeding from the features of the project and the currency itself. In addition, the regulations relating to securities, money transfers, collective investments and a number of other financial transactions can also be used for blockchain. ${ }^{54}$

The State Revenue Service of Latvia declared that cryptocurrency is a commodity or a product and is subject to value added taxation ${ }^{55}$ despite the obvious contradiction with the pre-judicial decision No. C-264/14 of the European Court of Justice of 2015, according to which Bitcoin is defined as a currency (means of payment), but not a commodity and is not subject to taxation on commodities. ${ }^{56}$ In 2017, amendments came into force in the Law on the Prevention of Money Laundering and Terrorism Financing, where virtual currency is defined as a digital representation of the value which can be transferred, stored or traded digitally and operates as a means of exchange, but has not been recognized as a legal means of payment, cannot be recognized as a banknote or coin, non-cash money and electronic money, and is not a monetary value accrued in the payment instrument. ${ }^{57}$

Bulgaria. The legal status of virtual currencies in Bulgaria remains uncertain. The Bulgarian National Revenue Agency (NRA) states that the personal income for

53 Peter Teffer, Estonia Tests Water for Own Virtual Currency, EUobserver, 24 August 2017 (Jun. 18, 2018), available at https://euobserver.com/eu-presidency/138796.

54 Bank of Lithuania, Bank of Lithuania Announces Its Position on Virtual Currencies and ICO More, 11 October 2017 (Jun. 18, 2018), available at https://www.lb.It/en/news/bank-of-lithuania-announcesits-position-on-virtual-currencies-and-ico.

55 Valsts ienēmumu dienests, Par darījumiem ar kriptovalūtu un nodokliem, 07. maijā, 2017 [Service of State Revenues, On Transactions and Taxes with Cryptocurrencies, 7 May 2017] (Jun. 18, 2018), available at http://m.lvportals.Iv/visi/e-konsultacijas/11918-par-darijumiem-ar-kriptovalutu-un-nodokliem/.

56 Judgment of the Court (Fifth Chamber) of 22 October 2015 (request for a preliminary ruling from the Högsta förvaltningsdomstolen - Sweden) - Skatteverket v. David Hedqvist (Case C-264/14) (Reference for a preliminary ruling - Common system of value added tax (VAT) - Directive 2006/112/ EC - Articles 2(1)(c) and $135(1)$ (d) to (f) - Services for consideration - Transactions to exchange the "bitcoin" virtual currency for traditional currencies - Exemption) (2015/C 414/08) (Jun. 18, 2018), available at https://publications. europa.eu/Iv/publication-detail/-/publication/3f2f909f-a23b-11e5-b528-01aa75ed71a1/language-Iv.

57 Law on the Prevention of Money Laundering and Terrorism Financing, "Latvijas Vēstnesis," 116(3900), 30.07.2008, "Ziṇotājs," 16, 28.08.2008 (Jun. 18, 2018), available at https://likumi.lv/ta/en/en/id/178987. 
physical persons from trading with virtual currencies must be declared with the annual tax return. The tax due is $10 \%$ from the annual basis of assessment. The NRA confirms that for the purpose of taxation the income from the sale of cryptocurrencies shall be treated equally as the income from the sale of financial assets. Where the transactions are carried out by a legal entity, the rules for corporate taxation shall be applicable. Nevertheless, the NRA stance is not clearly established, for the fact remains that virtual currencies are scarcely regulated in Bulgaria. Therefore, those requirements shall not apply to Bitcoin and other crypto exchanges..$^{58}$

Croatia and Slovenia are two countries with a certain common history, having both been part of the former Yugoslavia. It is therefore not surprising that the countries have similarities in their perspectives on blockchain technology and its applications.

Slovenian regulators have released a statement clarifying certain ambiguities related to Bitcoin and other digital currencies. The Tax Administration of the Republic of Slovenia said it received queries from taxpayers who were interested in the possible tax implications of bitcoin transactions. In response, the Tax Administration requested a formal decision from the Ministry of Finance, which, in reply, stated that Bitcoin remains a virtual currency - thus, it is not a "monetary asset" under Slovenian law..$^{59}$

In 2018, Croatian and Slovenian businesses and crypto-enthusiasts are coming together in Croatia to map out strategies that will create a framework for cryptocurrency policy in their countries. ${ }^{60}$

The Czech Republic previously had no law regulating cryptocurrency. An antimoney laundering law prepared by the Finance Ministry requires virtual currency exchanges to determine the identity of customers. Bitcoin users will no longer be able to "hide behind fake names or nicknames."

The Finance Ministry determined that it is possible to disguise links to criminal activity using virtual currency and that virtual currency poses the risk of tax fraud. The law has been endorsed by the House and now heads to the Senate. Cryptocurrency users have called the law a disaster. ${ }^{61}$

In Denmark, the two EU directives are transposed into Danish law in the Payment Services Act, which came into force in 2009. The previous Danish Act also regulated

58 Vassil Kostov, The Legal Framework of Cryptocurrencies in Bulgaria, Legal Net, 13 February 2018 (Jun. 18, 2018), available at https://1legal.net/en/blog-read129-the-legal-framework-of-cryptocurrencies-inbulgaria.

59 Nermin Hajdarbegovic, Slovenia Clarifies Position on Cryptocurrency Tax, CoinDesk, 24 December 2013 (Jun. 18, 2018), available at https://www.coindesk.com/slovenia-clarifies-position-cryptocurrency-tax/.

60 Croatia and Slovenia Cryptocurrency Enthusiasts Plan Self-Regulation, Crypto Economy, 21 February 2018 (Jun. 18, 2018), available at https://www.crypto-economy.net/en/croatia-and-slovenia-crypto currency-enthusiasts-plan-self-regulation/.

${ }_{61}$ Czech Republic Introduces Law Regulating (Restricting) Bitcoin, CCN.com, 31 January 2017 (Jun. 18, 2018), available at https://www.ccn.com/czech-republic-introduces-law-regulation-bitcoin/. 
a number of electronic systems for the payment of goods and services that were not covered by the two directives, e.g. electronic vouchers that represent a claim for a number of services rather than a monetary amount. Since Denmark wanted to continue regulating these systems, the concept of payment substitutes was introduced.

Virtual currencies as defined above are usually regulated by Danish law if they have an issuer. In that case, they are normally either e-money or payment substitutes. Whether they belong in one category or the other generally depends on whether they can be used with other persons than the issuer. If this is the case, they are usually defined as e-money.

Conversely, bitcoins and similar solutions with no central issuer are covered neither by European legislation nor by the Danish Payment Services Act. When virtual currencies are characterized as unregulated, this is the type referred to. The absence of regulation reflects the fact that there is no issuer against whom statutory claims can be made. ${ }^{62}$

Finland. Finland's Financial Supervisory Authority (FSA) issued a warning that initial coin/token offerings (ICOs/ITOs) and cryptocurrencies are risky and highly speculative investments. The FSA warned consumers of the volatile price of Bitcoin and other digital currencies, citing the EBA's 2013 publication on the risks of cryptocurrencies.

A new research paper released by the Bank of Finland has lauded the selfgoverning capacity of the bitcoin ecosystem. The paper states that

bitcoin cannot be regulated. There is no need to regulate it because as a system it is committed to the protocol as is and the transaction fees it charges the users are determined by the users independently of the miners' efforts.

The paper analyzes the fundamental underpinnings of Bitcoin, and explores an array of potential use-cases for the technology. The researchers conclude that Bitcoin's design as an economic system is revolutionary. Its apparent functionality and usefulness should further encourage economists to study this marvelous structure. ${ }^{63}$

France. The Bank of France has issued warnings similar to other European nations. There were informal indications that France might have been willing to allow virtual currency companies to operate as payment service providers under French law, and France has now indicated it will implement customer identity verification rules for virtual currency platforms. France plans to create a legal framework for raising funds

62 Anders Laursen \& Jon Hasling Kyed, Virtual Currencies, Danmarks Nationalbank, Monetary Review, $1^{\text {st }}$ Quarter 85, 87 (2014).

63 Gur Huberman et al., Monopoly Without a Monopolist: An Economic Analysis of the Bitcoin Payment System, Bank of Finland Research Discussion Papers 27 (2017) (Jun. 18, 2018), available at https://helda. helsinki.fi/bof/bitstream/handle/123456789/14912/BoF_DP_1727.pdf?sequence=1\&isAllowed=y. 
via cryptocurrencies and aims to become a leading center for offerings in bitcoinstyle digital currencies. ${ }^{64}$

Greece. The Bank of Greece adopted the EBA's warnings to consumers regarding virtual currencies. Greek payment services law cannot be applied to virtual currencies, given that virtual currency exchange services do not fall under the definition of payment services. ${ }^{65}$

Ireland. Ireland's Department of Finance has proposed the creation of a new blockchain working group to help create cohesive regulation across government agencies. Revealed in a new report, titled "Virtual Currencies and Blockchain Technology," the working group would aim to help bring a coordinated approach to rules around cryptocurrencies and monitor developments in blockchain technology, "addressing considerations raised by consumers, industry, the EU, and governments worldwide." ${ }^{\prime 66}$

Ireland has a national cryptocurrency IrishCoin which works with organizations associated with the tourism, hospitality and pubs \& entertainment sector, acting as a discount voucher, and for payment remittance. ${ }^{67}$

Iceland regulates virtual currencies as electronic currency through the Icelandic Exchange Act, which effectively prohibits entities from engaging in the exchange of virtual currency. ${ }^{68}$

Italy. A law requiring identification of parties in bitcoin transactions has been proposed in the Italian Parliament, but no regulation has appeared yet. Cryptocurrency is not legal tender. The Italian Ministry of Economic Development is working on a decree that aims at classifying the use of cryptocurrencies in the country and to list "service providers related to digital currencies." The Ministry of Economy and Finance, in its Press Release No. 22 of 2 February 2018, stated its commitment to examine the cryptocurrency phenomenon in Italy in all its aspects. ${ }^{69}$

64 Reuters Staff, France to Create Legal Framework for Cryptocurrency Offerings, Reuters, 22 March 2018 (Jun. 18, 2018), available at https://www.reuters.com/article/us-france-cryptocurrencies/france-tocreate-legal-framework-for-cryptocurrency-offerings-idUSKBN1GYOYE.

65 The Legal Framework of Virtual Currency Exchange Licensing and Operation in Greece, Law \& Technology (Jun. 18, 2018), available at https://lawandtech.eu/en/2017/11/29/virtual-currency-exchangelicensing-in-greece/.

66 Department of Finance, Discussion Paper: Virtual Currencies and Blockchain Technology (March 2018) (Jun. 18, 2018), available at http://www.finance.gov.ie/wp-content/uploads/2018/03/VirtualCurrencies-and-Blockchain-Technology-March-2018.pdf.

67 IrishCoin (Jun. 18, 2018), available at http://irishcoin.org.

68 Foreign Exchange Act No. 87, 17 November 1992, as amended up to 1 May 2013 (Jun. 18, 2018), available at https://www.cb.is/library/Skraarsafn---EN/Capital-surveillance/Foreign\%20Exchange\%20Act\%20-\%20 Copy\%20(1)\%20-\%20Copy\%20(1).pdf.

69 Valute virtuali: in consultazione pubblica lo schema di decreto per censire il fenomeno, Comunicato Stampa N²2 del 02/02/2018 [Virtual Currencies: In Public Consultation the Decree Scheme to Assess the Phenomenon, Bulletin Prints No. 22 of 2 February 2018] (Jun. 18, 2018), available at http://www. mef.gov.it/ufficio-stampa/comunicati/2018/documenti/comunicato_0022.pdf. 
The Luxembourg financial regulatory commission (CSSF) has issued a statement which concludes that virtual currencies are not legal tender. It warns that virtual currencies entail risks for their holders, and reminds financial services providers that carrying out activities in the financial sector requires authorization by the Minister of Finance and subjects them to CSSF supervision. ${ }^{70}$

The Netherlands does not regulate Bitcoin under its Act on Financial Supervision, but its national bank has released consumer warnings regarding the use of virtual currency. One court has ruled that it is a "medium of exchange" but not electronic money, and another court has classified virtual currency as an "object" subject to seizure. A Dutch court ruled in favor of a plaintiff who was owed a small amount of bitcoin in mining proceeds. In its ruling, the court expressly stated that Bitcoin represents a transferable value and has all the characteristics of a property right. $^{7}$

In Poland, cryptocurrencies are not illegal, but at the same time they are not legal tender. They are subject to capital gains taxes and value-added tax. Poland's Financial Ombudsman has called on the country's Ministry of Finance to regulate the local cryptocurrency industry, claiming that as Poland's cryptocurrency market is experiencing rapid growth, it should be subject to regulations that would protect customers of cryptocurrency exchanges. ${ }^{72}$

Portugal has been following trends that the European Union has laid down, such as the EU agreement to enforce closer regulation of cryptocurrencies, and such as an agreement by the European Council that proposed closer cryptocurrency regulations to prevent their abuse in money laundering and terrorism financing.

Portugal's Securities Market Commission has in the past revealed it was supervising banks and brokerages to keep a close eye on the Bitcoin hype that was sweeping the nation in December 2017. ${ }^{73}$

Spain. Virtual currencies are reportedly taxable as an electronic payment system under gambling law, but their treatment under other areas of law is unclear. Currently, the Spanish government is preparing blockchain-friendly legislation including

70 Communiques 2014, Commission de Surveillance du Secteur Financier (CSSF) [Sector Press Releases 2014, Financial Sector Surveillance Commission] (Jun. 18, 2018), available at http://www. cssf.lu/fileadmin/files/Publications/Communiques/Communiques_2014/Communique_virtual_ currencies_140214.pdf.

71 Rechtbank Amsterdam, ECLI:NL:RBAMS:2018:869, 14 February 2018 (Jun. 18, 2018), available at https:// uitspraken.rechtspraak.nl/inziendocument?id=ECLI:NL:RBAMS:2018:869.

72 Rzecznik Finansowy apeluje o uregulowanie finansowych technologii, PolskieRadio, 14.02.2017 [Finance Spokesperson Appeals for the Regulation of Finance Technology, PolskieRadio, 14 February 2017] (Jun. 18, 2018), available at https://www.polskieradio.pl/78/1227/Artykul/1727516,RzecznikFinansowy-apeluje-o-uregulowanie-finansowych-technologii.

73 Portugal's Regulator is Supervising Banks and Brokerages to Halt Bitcoin "Euphoria," CCN.com, 14 December 2017 (Jun. 18, 2018), available at https://www.ccn.com/portugals-regulator-issupervising-banks-and-brokerages-to-halt-bitcoin-euphoria/. 
possible tax breaks to attract companies in the emerging blockchain technology sector. $^{74}$

Sweden becomes the latest nation to see its central bank consider a digital currency, a process that for most has included at least some exploration of blockchainbased digital currencies. The Swedish national bank recently hinted that it has plans to create a national cryptocurrency called E-krona. ${ }^{75}$

Switzerland. The Swiss financial regulator has defined licensing requirements for bitcoin kiosk operators and said that virtual currency platforms are subject to the anti-money laundering act, but other regulation is unlikely because virtual currencies are perceived as a marginal phenomenon.

The Swiss Financial Market Supervisory Authority (FINMA) revealed a potential ICO regulation which would use a three-tier system for classifying tokens based on their use and the rights and benefits they confer on a purchaser.

The proposed plan, which has not yet been implemented, sets forth four groups of tokens/coins:

1) payment tokens (cryptocurrencies), which would not be classified as securities;

2) utility tokens, which would generally not be considered securities if they have a use or can be exchanged for a service. However, the purchaser must be able to use the token at the time of the ICO;

3) asset tokens, which are widely considered securities and are subject to Swiss securities law;

4) hybrid tokens, which will have to be assessed on a case-by-case basis. ${ }^{76}$

The United Kingdom is a leader in cryptocurrency integration and one of the most favorable and convenient jurisdictions for conducting a cryptocurrency business. However, the final position of the government on legal regulation is still not worked out. The income (profit) of an economic entity is subject to capital gains tax, corporate tax and income tax. ${ }^{77}$

74 Giulio Prisco, Government of Spain Considers Blockchain-Friendly Regulations, Bitcoin Magazine, 22 February 2018 (Jun. 18, 2018), available at https://bitcoinmagazine.com/articles/government-spainconsiders-blockchain-friendly-regulations/.

75 E-krona, the Next National Cryptocurrency of Sweden, Crypto Economy, 2 February 2018 (Jun. 18, 2018), available at https://www.crypto-economy.net/en/e-krona-the-next-national-cryptocurrencyof-sweden/.

76 FINMA, FINMA Publishes ICO Guidelines, Press Release, 16 February 2018 (Jun. 18, 2018), available at https://www.finma.ch/en/news/2018/02/20180216-mm-ico-wegleitung/.

77 Revenue and Customs Brief 9 (2014): Bitcoin and Other Cryptocurrencies, Policy Paper, GOV.UK, 3 March 2014 (Jun. 18, 2018), available at https://www.gov.uk/government/publications/revenueand-customs-brief-9-2014-bitcoin-and-other-cryptocurrencies/revenue-and-customs-brief-9-2014bitcoin-and-other-cryptocurrencies. 


\section{Conclusion}

Cryptocurrency is a new product of historical development and progress. It has become a liquid, easy to implement medium of exchange, alongside fiat money. Cryptocurrency performs one of the most important functions inherent in moneythe exchange of information of the community, which recognizes it as an appeal. Cryptocurrency has already been recognized as a means of exchange. Therefore, in the near future circulation and mining of cryptocurrencies will become an integral part of the market economy.

E-money is also digital, however the main difference is that e-money is issued not only by the State, but also by commercial banks, creating a certain imbalance. The issuer of cryptocurrency is decentralized, and it exists only virtually.

Virtual currency possesses the nature of obligations rights as well as property rights, since it may be both a means of payment and a commodity.

A number of countries demonstrate a complete inability to respond adequately and competently to innovations and technological progress. But the emergence of decentralized systems and cryptocurrency will inevitably lead to evolutionary changes in the international legal system.

Even today there is already an international cryptocurrency community that does not have any single coordinating center. Only progressive jurisdiction and state regulation of cryptocurrency activity will allow the creation of the conditions that will ensure the implementation of legitimate and safe cryptocurrency relations.

It is quite obvious that it is necessary to determine the essence and nature of cryptocurrencies, as well as their legal status and functions, alongside cash and e-money.

Legal science is on the threshold of the theory of cryptocurrencies.

\section{References}

Camera G. \& Casari M. The Coordination Value of Monetary Exchange: Experimental Evidence, 6(1) American Economic Journal: Microeconomics 290 (2014).

Camera G. et al. Money and Trust Among Strangers, 110(37) Proceedings of the National Academy of Sciences 14889 (2013).

Chuen D.L.K. Handbook of Digital Currency: Bitcoin, Innovation, Financial Instruments, and Big Data (London: Elsevier, 2015).

Goodhart C.A.E. The Two Concepts of Money: Implications for the Analysis of Optimal Currency Areas, 14(3) European Journal of Political Economy 407 (1998).

Guttmann B. The Bitcoin Bible: All You Need to Know About Bitcoins (Germany: BoD, 2013).

Laursen A. \& Kyed J.H. Virtual Currencies, Danmarks Nationalbank, Monetary Review, $1^{\text {st }}$ Quarter 85 (2014). 


\section{Information about the author}

Irina Cvetkova (Riga, Latvia) - Lecturer, Baltic International Academy (4 Lomonosova St., Riga, LV-1003, Latvia; e-mail: cvetkova@inbox.lv). 